\title{
Orientation Selectivity in the Retina: ON Cell Types and Mechanisms
}

\author{
-Paride Antinucci, $\odot$ Fatima Abbas, and $\odot$ Paul R. Hunter \\ Centre for Developmental Neurobiology, King's College London, Guy's Campus, London SE1 1UL, United Kingdom \\ Review of Nath and Schwartz and of Venkataramani and Taylor
}

Orientation selectivity was first described in cat primary visual cortex by Hubel and Wiesel (1962) as the selectivity of neuronal firing for elongated visual stimuli oriented along a specific axis. Shortly afterward, Levick (1967) identified orientation-selective ganglion cells (OSGCs) in the rabbit retina, suggesting that orientation-specific information is already evident in the output neurons of the retina. Since then, orientation-selective cells have been described in many vertebrate and invertebrate visual systems, including primates (Hubel and Wiesel, 1968), rodents (Niell and Stryker, 2008), fish (Nikolaou et al., 2012), and insects (Fisher et al., 2015). Notably, orientation selectivity has also been characterized even earlier in visual processing, in amacrine cells (Bloomfield, 1994; MurphyBaum and Taylor, 2015), a class of inhibitory retinal neurons modulating ganglion cell responses. In addition to their preferred angular selectivity, orientation-selective cells are classified by their luminance polarity. For example, OFF-OSGCs have been described in the rabbit retina due to their response preference for dark (negative con-

Received May 10, 2016; revised June 16, 2016; accepted June 21, 2016.

This work was supported by a King's College London Health Schools PhD studentship sponsored by Medical Research Council Grant 1413592 (P.A.), and a Biotechnology and Biological Sciences Research Council project grant BB/L004992/1 (P.R.H.). We thank Drs. Martin Meyer and Federico Grillo for helpful discussions and critical reading of the manuscript.

The authors declare no competing financial interests.

Correspondence should be addressed to either Paride Antinucci or Paul

R. Hunter, 4th Floor, New Hunt's House, London SE1 1UL, UK, E-mail: paride.antinucci@kcl.ac.uk or paul.hunter@kcl.ac.uk.

DOI:10.1523/JNEUROSCI.1527-16.2016

Copyright $\odot 2016$ the authors $\quad 0270-6474 / 16 / 368064-03 \$ 15.00 / 0$ trast, or "OFF") stimuli and suppression by light (positive contrast, or "ON") stimuli (Venkataramani and Taylor, 2010).

Providing a mechanistic understanding of the circuitry that generates neuronal feature selectivity is a core goal for visual neuroscientists. Such focus has provided an exquisitely detailed picture of the circuit and synaptic mechanisms generating direction selectivity (selectivity to motion of a stimulus in a particular direction) in the mouse retina and fly optic lobe (for review, see Borst and Helmstaedter, 2015). By comparison, our understanding of the mechanisms generating orientation selectivity in the retina is still rudimentary, largely due to the lack of specific molecular markers. Additionally, there is a drive to characterize the diversity of ganglion cell types, or feature channels, based on their functional, morphological, and genetic profiles (Baden et al., 2016). To date, how many OSGC types are present in the retina and how evolutionarily conserved they are across species remains unclear.

To start addressing these gaps in our understanding, two publications in The Journal of Neuroscience have undertaken large-scale single-cell analyses to examine the electrophysiological, morphological, and pharmacological signatures of newly identified ON-OSGCs in mouse (Nath and Schwartz, 2016) and rabbit (Venkataramani and Taylor, 2016) retinae. In particular, the ON-OSGCs characterized by the authors fall into the following two morphologically and physiologically distinct categories: cells tuned to horizontally oriented bars (found in both mouse and rabbit retinae); and cells tuned to vertically oriented bars (observed in mouse only). A summary of these results is presented in Figure 1.

One property that might underlie ganglion cell receptive field properties is dendritic morphology, including stratification and spatial organization within the inner plexiform layer (IPL). For example, the alignment of dendrites along a preferred direction has a role in generating direction selectivity in some ganglion cells (Kim et al., 2008). To describe the dendritic morphology of ON-OSGCs and assess its potential role in generating orientation tuning, Nath and Schwartz (2016) and Venkataramani and Taylor (2016) filled functionally identified ON-OSGCs with fluorescent dyes. In the mouse, the dendrites of both vertical and horizontal ON-OSGCs stratified in both the ON and OFF IPL layers, while in the rabbit, the dendrites of horizontal ON-OSGCs stratified exclusively in the ON layer (Fig. $1 A$ ). The seemingly functionally irrelevant wiring in the OFF layer of mouse ONOSGCs suggests an unexplored complexity in the receptive field properties of these cells. Strikingly, both research groups found that horizontal ON-OSGCs cells have elongated dendritic arbors oriented according to their stimulus orientation selectivity (i.e., horizontally oriented). Although this morphological bias could contribute to the tuning of horizontal ON-OSGCs, the extent to which this feature is necessary to generate orientation selectivity is unclear, because no significant bias was detected for vertically tuned cells. 
Presynaptic mechanisms could also produce orientation selectivity in ON-OSGCs. Therefore, to reveal the synaptic inputs received by these cells, Nath and Schwartz (2016) and Venkataramani and Taylor (2016) used whole-cell voltage-clamp recordings to isolate excitatory and inhibitory conductances. Notably, mouse and rabbit horizontal ON-OSGCs appeared to receive similar synaptic inputs. In particular, they received excitatory inputs tuned to the preferred orientation (i.e., horizontal) and inhibitory inputs tuned to the orthogonal orientation [i.e., vertical $\left(90^{\circ}\right.$ angular distance); Fig. 1B]. Mouse vertical ON-OSGCs also received excitatory inputs tuned to the preferred orientation (i.e., vertical), but, unlike horizontal ON-OSGCs, they received variable inhibitory inputs. Although individual vertical ON-OSGCs did receive tuned inhibitory inputs, these inputs were not orthogonal to the preferred orientation in all cases (Nath and Schwartz, 2016, their Fig. $7 D, F)$. Consequently, when data were pooled from the whole population of vertical ON-OSGCs, it appeared that inhibitory inputs have an untuned response profile (Nath and Schwartz, 2016, their Fig. 6G).

To further determine the precise contribution of inhibition to ON-OSGC orientation tuning, both groups pharmacologically blocked inhibitory neurotransmission. Venkataramani and Taylor (2016) demonstrated that the spiking of rabbit horizontal ON-OSGCs was rendered orientation selective through GABA-mediated mechanisms (Venkataramani and Taylor, 2016, their Fig. $7 A, B)$. The main effect of blocking $\mathrm{GABA}_{\mathrm{A}}$ receptors was a dramatic loss of orientation selectivity in the inhibitory inputs (Venkataramani and Taylor, 2016, their Fig. 7O), indicating a crucial role played by inhibition from amacrine cells. In particular, the authors proposed a circuit mechanism whereby inhibitory inputs are suppressed during preferred orientation stimulation, possibly through disinhibition from a preferred orientation-selective GABAergic amacrine cell that inhibits another amacrine cell synapsing directly onto the horizontal ON-OSGC (Venkataramani and Taylor, 2016, their Fig. 11). As mentioned above, orientation-selective amacrine cell types have previously been described in the rabbit retina (Bloomfield, 1994; Murphy-Baum and Taylor, 2015), but the extent to which their outputs contribute to OSGC tuning remains unclear.

Nath and Schwartz (2016) did not show the effects of blocking inhibition on the spiking of mouse ON-OSGCs. They instead focused on the changes in excitatory and inhibitory conductances upon

\section{ON Orientation-selective RGCs}

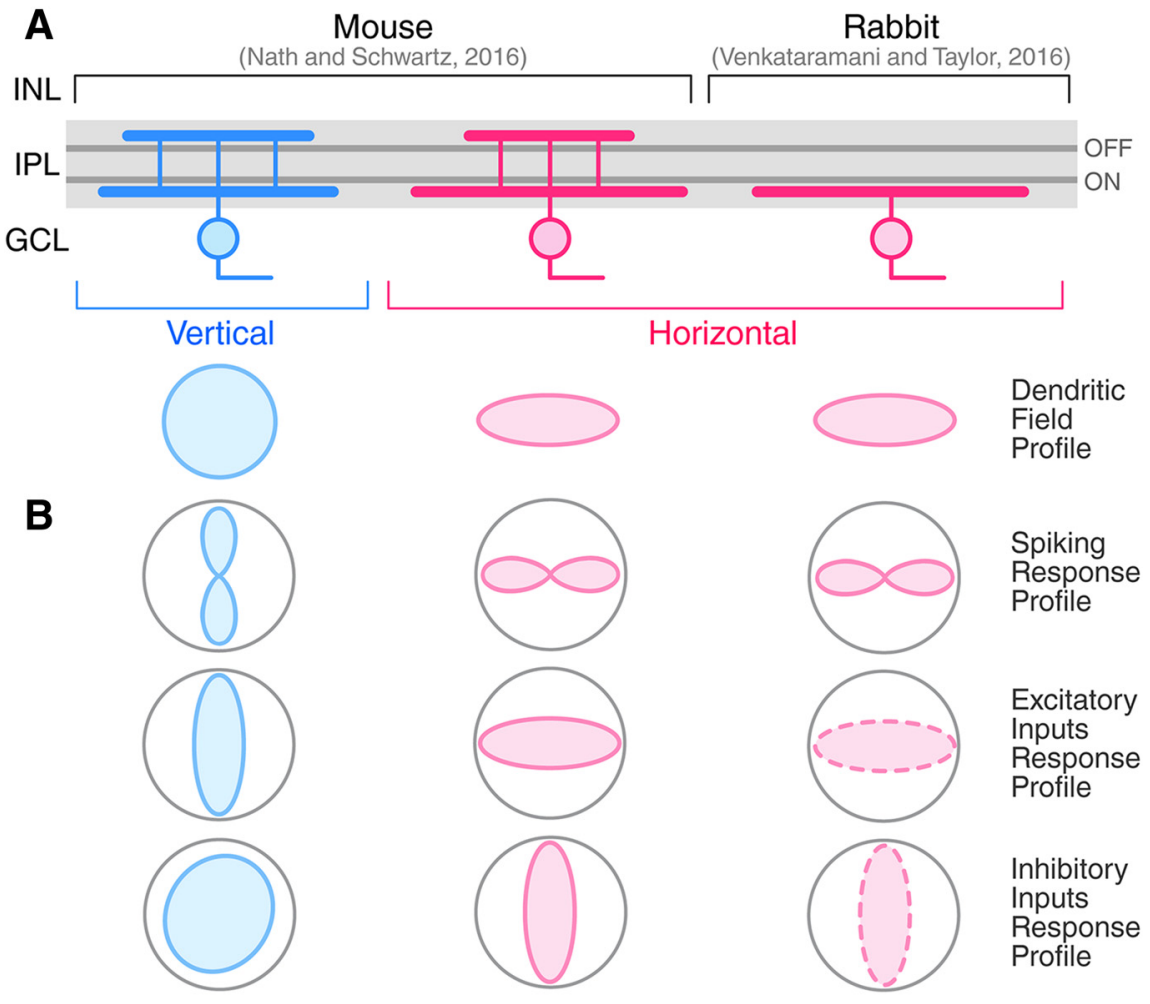

Figure 1. $\quad \boldsymbol{A}, \boldsymbol{B}$, Schematic summarizing the morphological $(\boldsymbol{A})$ and physiological $(\boldsymbol{B})$ properties of $0 \mathrm{~N}-0 \mathrm{SGC}$ in mouse (Nath and Schwartz, 2016) and rabbit (Venkataramani and Taylor, 2016) retinae. A, Dendritic stratification (top) in the IPL and dendritic field profiles (bottom) of ON-OSGCS. Dark gray lines in the IPL indicate OFF and ON choline acetyltransferase (ChAT) strata. INL, Inner nuclear layer; GCL, ganglion cell layer. $\boldsymbol{B}$, Response profiles of ON-OSGC spiking (top), excitatory inputs (middle), and inhibitory inputs (bottom). Dashed lines of excitatory and inhibitory input response profiles in rabbit horizontal ON-OSGCS indicate the estimated profiles from responses recorded during preferred vs orthogonal orientation stimulation. Note the high degree of morphological and physiological homology between mouse and rabbit horizontal ON-OSGCs (magenta).

inhibition block. Individually blocking either glycine or $\mathrm{GABA}_{\mathrm{A}}$ receptors changed the peak amplitude of excitatory and inhibitory inputs but, surprisingly, did not produce any significant change in their orientation tuning (Nath and Schwartz, 2016, their Fig. 8 F-H). When blocked simultaneously, the tuning of excitatory inputs remained unaffected, but the tuning of inhibitory inputs was abolished as a consequence of the total loss of inhibitory currents (Nath and Schwartz, 2016, their Fig. $8 A, C)$. Overall, these results in the mouse suggest that there is a substantial level of redundancy among glycinergic and GABAergic mechanisms, and that orientation selectivity in mouse $\mathrm{ON}$ OSGCs could be generated through both tuned excitatory inputs independent of inhibition and, at least in horizontal ON-OSGCs, a combination of tuned inhibitory inputs from different classes of amacrine cells. It is intriguing that the tuning of vertical ON-OSGCs, which do not possess elongated dendritic fields, seems to result almost exclusively from inhibition-independent tuned excitatory inputs. Future experiments will be required to precisely determine how the tuning of mouse ON-OSGC spiking is modulated by amacrine cell inhibition, and to what extent tuned excitatory inputs alone can generate the orientation selectivity of ON-OSGC spiking.

Together, these studies demonstrate the presence of novel morphologically and physiologically defined ON orientationselective ganglion cell types in both mouse and rabbit retinae. The substantial degree of homology between horizontal ON-OSGCs in these two species suggests that conserved features and mechanisms might underlie retinal orientation selectivity across mammalian species. However, there are clear differences, such as the key requirement of GABAergic inhibition for rabbit ON-OSGC tuning not observed in the mouse and the dendritic stratification in the OFF IPL strata of mouse ON-OSGCs that is not present in the rabbit, that would suggest different mechanisms between species.

The morphological bias of horizontal ON-OSGCs not found in mouse vertical ON-OSGCs raises the question, what is the 
advantage of generating this bias if it is not essential for tuning? The following two possible scenarios could explain this dichotomy: (1) these two ON-OSGCs have different, more complex receptive field properties, not revealed by the stimulus set used, that would allow classification into distinct functional groups; and (2) they use the same mechanisms to generate orientation selectivity and differ only in their preferred stimulus orientation. If scenario (2) is correct, the difference in their dendritic morphology is coincidental, not causative of orientation selectivity. Experiments mapping presynaptic inputs using 3D electron microscopy tracing (Briggman et al., 2011), high-resolution immunohistochemistry (Sigal et al., 2015), or neurotransmitter sensors/uncaging (Yonehara et al., 2013; Vlasits et al., 2016) would provide evidence on whether orientation selectivity is a consequence of a bias in the distribution of inputs on their dendritic arbors.

These studies also highlight the diversity of OSGC subtypes and the fraction of the overall retinal output they represent. In a previous study, Venkataramani and Taylor (2010) described two types of rabbit cardinal axes-tuned OFF-OSGCs, and in Venkataramani and Taylor (2016) they conclude that, collectively, OSGCs account for $\sim 5 \%$ of all rabbit ganglion cells. In a comprehensive functional classification of mouse ganglion cells, Baden et al. (2016) identified ON, OFF, and ONOFF OSGCs comprising different cardinally and obliquely tuned types, which collectively represent $\sim 15 \%$ of the retinal output. Given the striking abundance of OSGCs in these two mammalian species, as well as reports of OSGCs in primates (Passaglia et al., 2002), it is likely that these cells directly contribute to orientation selectivity in higher visual centers. In line with this idea, several studies in rodents and primates have identified orientationselective neurons in noncortical areas, such as the dorsal lateral geniculate nucleus (dLGN; Cheong et al., 2013; Piscopo et al., 2013) and superior colliculus (Wang et al., 2010). Further supporting this possibility, recent studies have shown that mouse dLGN axonal projections provide orientation-selective inputs to primary visual cortex (Sun et al., 2016) and that in- activating primary visual cortex does not change the orientation tuning of dLGN neurons (Zhao et al., 2013). The identification of genetic markers allowing the selective labeling or ablation of OSGC types as well as trans-synaptic tracing to their brain targets (Cruz-Martín et al., 2014) will provide crucial information regarding the extent that OSGCs contribute to orientation selectivity in higher visual centers. Such genetic markers will also be essential to dissect the presynaptic cellular components and mechanisms underlying the emergence of orientation selectivity in OSGCs.

\section{References}

Baden T, Berens P, Franke K, Román Rosón M, Bethge M, Euler T (2016) The functional diversity of retinal ganglion cells in the mouse. Nature 529:345-350. CrossRef Medline

Bloomfield SA (1994) Orientation-sensitive amacrine and ganglion cells in the rabbit retina. J Neurophysiol 71:1672-1691. Medline

Borst A, Helmstaedter M (2015) Common circuit design in fly and mammalian motion vision. Nat Neurosci 18:1067-1076. CrossRef Medline

Briggman KL, Helmstaedter M, Denk W (2011) Wiring specificity in the direction-selectivity circuit of the retina. Nature 471:183-188. CrossRef Medline

Cheong SK, Tailby C, Solomon SG, Martin PR (2013) Cortical-like receptive fields in the lateral geniculate nucleus of marmoset monkeys. J Neurosci 33:6864-6876. CrossRef Medline

Cruz-Martín A, El-Danaf RN, Osakada F, Sriram B, Dhande OS, Nguyen PL, Callaway EM, Ghosh A, Huberman AD (2014) A dedicated circuit links direction-selective retinal ganglion cells to the primary visual cortex. Nature 507:358-361. CrossRef Medline

Fisher YE, Silies M, Clandinin TR (2015) Orientation selectivity sharpens motion detection in Drosophila. Neuron 88:390-402. CrossRef Medline

Hubel DH, Wiesel TN (1962) Receptive fields, binocular interaction and functional architecture in the cat's visual cortex. J Physiol 160: 106-154. CrossRef Medline

Hubel DH, Wiesel TN (1968) Receptive fields and functional architecture of monkey striate cortex. J Physiol 195:215-243. CrossRef Medline

Kim IJ, Zhang Y, Yamagata M, Meister M, Sanes JR (2008) Molecular identification of a retinal cell type that responds to upward motion. Nature 452:478-482. CrossRef Medline

Levick WR (1967) Receptive fields and trigger features of ganglion cells in the visual streak of the rabbits retina. J Physiol 188:285-307. CrossRef Medline
Murphy-Baum BL, Taylor WR (2015) The synaptic and morphological basis of orientation selectivity in a polyaxonal amacrine cell of the rabbit retina. J Neurosci 35:13336-13350. CrossRef Medline

Nath A, Schwartz GW (2016) Cardinal orientation selectivity is represented by two distinct ganglion cell types in mouse retina. J Neurosci 36:3208-3221. CrossRef Medline

Niell CM, Stryker MP (2008) Highly selective receptive fields in mouse visual cortex. J Neurosci 28:7520-7536. CrossRef Medline

Nikolaou N, Lowe AS, Walker AS, Abbas F, Hunter PR, Thompson ID, Meyer MP (2012) Parametric functional maps of visual inputs to the tectum. Neuron 76:317-324. CrossRef Medline

Passaglia CL, Troy JB, Rüttiger L, Lee BB (2002) Orientation sensitivity of ganglion cells in primate retina. Vision Res 42:683-694. CrossRef Medline

Piscopo DM, El-Danaf RN, Huberman AD, Niell CM (2013) Diverse visual features encoded in mouse lateral geniculate nucleus. J Neurosci 33:4642-4656. CrossRef Medline

Sigal YM, Speer CM, Babcock HP, Zhuang X (2015) Mapping synaptic input fields of neurons with super-resolution imaging. Cell 163: 493-505. CrossRef Medline

Sun W, Tan Z, Mensh BD, Ji N (2016) Thalamus provides layer 4 of primary visual cortex with orientation- and direction-tuned inputs. Nat Neurosci 19:308-315. CrossRef Medline

Venkataramani S, Taylor WR (2010) Orientation selectivity in rabbit retinal ganglion cells is mediated by presynaptic inhibition. J Neurosci 30:15664-15676. CrossRef Medline

Venkataramani S, Taylor WR (2016) Synaptic mechanisms generating orientation selectivity in the ON pathway of the rabbit retina. J Neurosci 36:3336-3349. CrossRef Medline

Vlasits AL, Morrie RD, Tran-Van-Minh A, Bleckert A, Gainer CF, DiGregorio DA, Feller MB (2016) A role for synaptic input distribution in a dendritic computation of motion direction in the retina. Neuron 89:1317-1330. CrossRef Medline

Wang L, Sarnaik R, Rangarajan K, Liu X, Cang J (2010) Visual receptive field properties of neurons in the superficial superior colliculus of the mouse. J Neurosci 30:16573-16584. CrossRef Medline

Yonehara K, Farrow K, Ghanem A, Hillier D, Balint K, Teixeira $M$, Jüttner J, Noda $M$, Neve RL, Conzelmann KK, Roska B (2013) The first stage of cardinal direction selectivity is localized to the dendrites of retinal ganglion cells. Neuron 79:1078-1085. CrossRef Medline

Zhao X, Chen H, Liu X, Cang J (2013) Orientation-selective responses in the mouse lateral geniculate nucleus. J Neurosci 33: 12751-12763. CrossRef Medline 